\title{
Adaptation strategies of copepods (superfamily Centropagoidea) in the White Sea $\left(66^{\circ} \mathrm{N}\right)$
}

\author{
Daria M. Martynova • Martin Graeve • \\ Ulrich V. Bathmann
}

Received: 3 December 2007 / Revised: 5 September 2008 / Accepted: 8 September 2008 / Published online: 7 October 2008

(C) The Author(s) 2008. This article is published with open access at Springerlink.com

\begin{abstract}
Seasonal dynamics of major biochemical features were studied for three abundant egg-diapausing copepods Acartia bifilosa, Centropages hamatus and Temora longicornis, in the White Sea $\left(66^{\circ} \mathrm{N}\right)$, between June 2002 and September 2002. Dry weight (DW) and prosome length varied from $0.54 \mu \mathrm{g} \mathrm{ind}^{-1}$ and $0.163 \pm 0.012 \mathrm{~mm}$ (A. bifilosa, CI) to $9.58 \pm 0.72 \mu \mathrm{g}$ ind $^{-1}$ and $1.135 \pm$ $0.167 \mathrm{~mm}$ ( $C$. hamatus, females). $\mathrm{C}_{\text {org }}$ and $\mathrm{N}_{\text {org }}$ content reached up to $5.91 \pm 0.44$ and $1.23 \pm 0.09 \mu \mathrm{g}$ ind $^{-1}$ (C. hamatus, females). Protein and lipid content varied greatly from 31.8 to $67.3 \%$ DW and from 8.7 to $42.6 \%$ DW, respectively. These species show somewhat different biology compared to species at lower latitudes. The copepods use lipid stores to survive during short-term food shortage (e.g. in autumn) and successfully complete their life cycle. In the isolated White Sea during last post-glacial period, species probably evolved some special biochemical features (especially wax esters presence). Food quality demands and long ice coverage are possible factors limiting early development of species in spring.
\end{abstract}

Keywords Acartia.Temora Centropages . The White Sea $\cdot$ Life cycle strategies

D. M. Martynova $(\bowtie)$

The White Sea Biological Station,

Zoological Institute of Russian Academy of Sciences, Universitetskaya nab., 1, 199034 St Petersburg, Russia

e-mail: daria.martynova@gmail.com

M. Graeve · U. V. Bathmann

Alfred-Wegener-Institute für Polar und Meeresforschung,

Am Handelshafen 12, 27570 Bremerhaven, Germany

\section{Introduction}

Several biochemical features, which change during copepod life cycles, could all be used as an indicator of the current species adaptation to environmental conditions. Seasonal fluctuations in chemical composition and body weight are typical for animals from temperate and polar regions (Auel and Hagen 2005; Lee et al. 2006). Crustacean body size depends on temperature as reported for both freshwater Cladocera and marine copepods (Mauchline 1998; Hirst and Lampitt 1998). The same correlations were found for dry weight (DW) and prosome length (Viitasalo et al. 1995; Hirst and Lampitt 1998), food concentration (Koski et al. 1998) and predator abundance (Wahlstroem et al. 2000). The energy (lipid) content also varies during the season and depends on food availability (Cripps and Hill 1998; Nanton and Castel 1999; Hygum et al. 2000). Lipid storage is especially important for polar copepod species, increasing over the course of the growing season in preparation for winter diapause (Bathmann et al. 1993; Kosobokova 1999).

Storage lipids of copepods play an important role during reproduction, food scarcity, ontogeny and diapause, as shown by studies in various oceanic regions. Lipid content also varies geographically. Copepods found in polar, upwelling and coastal biomes are characterized by large lipid stores (Lee et al. 2006). In contrast, crustaceans from the temperate or tropical ecosystems show only small lipid reserves. Thus, tropical species (Acartia sinjiensis) have low lipid content (from 11 to $26 \%$ from DW), whereas the same parameter for Arctic copepods (Calanus glacialis, Metridia longa) varies from 37 to 54\% (Lee 1975a; McKinnon et al. 2003). Diapausing copepods, which enter deep waters after feeding on phytoplankton during spring/ summer blooms or at the end of upwelling periods, are 
characterized by large oil sacs filled with wax esters (WEs; Hygum et al. 2000), which in turn could be utilized during starvation (Lee 1975b). The thermal expansion and compressibility of these WEs may allow copepods in diapause to be neutrally buoyant in cold deep waters, reducing energy costs to remain at these depths (Lee et al. 2006). Lipid droplets are often found in zooplankton ovaries, and a portion of these droplets can be transferred to developing oocytes. Various functions the storage lipids serve during different life history stages of zooplankton are very complex and are still not understood fully (Lee et al. 2006). In addition to lipids, proteins perform both structural and fermentative functions, but much less is known about the role of these compounds during starvation (Helland et al. 2003). Usually, structural proteins are not used as energy source by copepods, but they may be utilized during long starvation periods once all storage lipids have been depleted.

The content of organic carbon and nitrogen can be used as an indicator for physiological state, as has been shown for lipid/protein content (Postel et al. 2001). The lipid versus protein ratio can be estimated from the $\mathrm{CN}$ ratio (Childress and Nygaard 1974; Anger 2001). Usually high percentage of organic $\mathrm{N}$ indicates relatively high protein (low lipid) content, while high content of organic carbon simultaneously shows high lipid content. To date, a large body of information about the organic carbon and nitrogen content in copepods is available. Organic carbon content varies from 28 to $68 \%$ of copepod DW with an average of 44.7\% (Mauchline 1998). Pelagic species inhabiting the upper layers of tropical and temperate waters have lower amounts of organic carbon than bathypelagic animals from polar seas. Organic nitrogen content usually varies from 5.2 to $15.8 \%$ of DW (see, for review, Mauchline 1998).

As mentioned earlier, copepods may be divided into two groups according to the mode of diapause: (1) as copepodit or (2) as latent or resting eggs (Steidinger and Walker 1984). The first type of life cycle strategy usually occurs in the Arctic species, such as Calanus glacialis, that inhabit the White Sea. The active phase of this species coincides with the phytoplankton bloom when animals feed, grow, mature and reproduce. They then store lipids and overwinter in the copepodit stage (Kosobokova 1999).

The second group of key copepod species inhabiting the White Sea is represented by the superfamily Centropagoidea (Acartia bifilosa, Centropages hamatus and Temora longicornis). These copepods overwinter in a resting egg phase (second type of life cycle) and usually have one to three generations during the productive season (Prygunkova 1974; Pertzova 1974). They dominate the biomass and are subdominate in abundance, following the Tintinnids (Ciliophora), from late July until the beginning of September in the upper water layer $0-25 \mathrm{~m}$, preferring a wide water temperature range from +10 to $+17^{\circ} \mathrm{C}$ and higher
(Prygunkova 1974; Usov and Zubakha 2004; Martynova et al. unpublished). It is probable that these species play an important role in the productive period (mostly summertime) in the White Sea, when cold water species (Calanus glacialis, Pseudocalanus spp. and Metridia longa) are absent in upper water layers (Berger et al. 2003). It was reported by Prygunkova (1974) that the number of generations through the summer season was closely connected with summer temperature: in cold years, these species were able to produce only one generation, while in warm years they produce up to three generations. Moreover, A. bifilosa has a much longer reproductive season in the White Sea because of its wider optimal temperature range when compared to T. longicornis and C. hamatus (Usov and Zubakha 2004). On the other hand, all these species are faced with the harsh environment of a short Arctic summer (e.g. temperature dynamics and food shortage, Berger et al. 2003) during their life cycle in contrast to the same species in the mid-Atlantic. Thus, we expect that the latter may induce seasonal differences in both, their biochemical and morphological features. Until recently, very little was known about the regional variability in these parameters for these species until recently. The only existing investigation from the Arctic region describing wet weight and body size of species from these three genera was conducted 40 years ago in the White Sea (Pertzova 1967). Biochemical changes in such copepods due to their life cycle, especially for the White Sea, have not yet been described. Therefore, the present study predominantly focuses on investigating the possible relationships between the dynamics of biochemical features, some environmental conditions and the life cycle patterns of three key copepod species (Acartia bifilosa, Centropages hamatus and Temora longicornis), inhabiting the White Sea.

\section{Materials and methods}

Sampling: copepod prosome length and $\mathrm{CN}$ measurements

Sampling of zooplankton was conducted from June 2002 to September 2002. At weekly intervals, a zooplankton sample ( $0-15 \mathrm{~m}$ vertical net tow) was taken close to the White Sea Biological Station, Cape Kartesh, Kandalaksha Bay (the White Sea, $66^{\circ} 20.2 \mathrm{~N} ; 33^{\circ} 38.9 \mathrm{E}$ ) at weekly intervals. Zooplankton samples were immediately transported to the shore laboratory or, during the cruise, to the shipboard laboratory. Copepods from three species, inhabiting the upper $(0-15 \mathrm{~m})$ water layer, were studied: Acartia bifilosa (Giesorecht, 1882), Centropages hamatus (Lilljeborg, 1853) and Temora longicornis (O.F. Müller, 1792). The copepods from each species were sorted to stage, and 100200 animals from each stage of every species were taken 
for each measurement with at least three replicates, where possible. The copepods for $\mathrm{CN}$ analysis were placed onto precombusted and preweighted $\left(24 \mathrm{~h},+190^{\circ} \mathrm{C}\right)$ Whatman $\mathrm{GF} / \mathrm{C}$ glass fiber filters (pore size $1.2 \mu \mathrm{m}$ ); these filters were then gently washed with prefiltered $(0.2 \mu \mathrm{m})$ seawater on $0.1 \mathrm{~Pa}$ vacuum. Several drops of $0.1 \% \mathrm{HCl}$ were added to remove any inorganic carbon. Subsequently, filters were washed with 3-5 $\mathrm{ml}$ of distilled water to remove the salts, placed in precombusted aluminum foil envelopes and dried at $56^{\circ} \mathrm{C}$ for $24 \mathrm{~h}$. Filters were cooled on silica-gel to constant weight and then weighted to $0.05 \mathrm{mg}$ accuracy. Before the $\mathrm{CN}$ analysis, the filters were stored in a cool dark container with silica-gel. Measurements of organic carbon (C) and nitrogen $(\mathrm{N})$ were conducted using a Carlo Erba NA 1500 analyser at AWI (Bremerhaven, Germany). A total of 306 samples were analyzed. The remaining zooplankton were fixed with formaldehyde-ethanol solution (final concentration of formaldehyde was $2 \%$ ) for later prosome measurements. Prosome length (PL) of species and stages were measured on thirty copepods, with $25 \mu \mathrm{m}$ accuracy, under the dissection microscope at $40 \times$ magnification. Seasonal observations (Table 1) were only possible for Acartia, since Temora and Centropages species only appear abundantly in plankton communities at the end of July.

Temperature and feeding conditions

Temperature and salinity measurements were performed by MIDAS CTD profiles with $0.1^{\circ} \mathrm{C}$ and 0.01 PSU accuracy through the $0-15 \mathrm{~m}$ water layer at the vicinity of zooplankton sampling sites. Average temperature was recalculated for the water layer of the zooplankton sample. Organic carbon and phytopigment [Chlorophyll $a$ (Chl. $a$ ) and phaeophytin] content in particulate organic matter (potential food) was measured at the sea surface using standard techniques (Harris et al. 2000). To recalculate Chl. $a$ into organic carbon terms, the conversion factor, PPC (Chl. $a$ pigment per carbon, $\mu \mathrm{g} \mu \mathrm{g}^{-1}$ ), was used (Smetacek and Hendrikson 1979; Vetrov 2008). Further analyses were applied to establish whether temperature or food quantity affect biochemical differences through the season.

Protein analysis

The subsamples of zooplankton catch were placed in a glass jar on ice. Triplicate samples of alive 100-200 animals from each species and developmental stage were sorted from the total sample using a dissecting microscope $(40 \times$ magnification). For sorting, the copepods were placed onto Petri dishes (20 mm diameter) filled with cold filtered $(0.2 \mu \mathrm{m})$ seawater and transferred to $2 \mathrm{ml}$ sterile preweighted Eppendorf cups. The cups were gently washed with cold distilled water, and thereafter, the water was removed with Kleenex tissues. The samples were immediately frozen $\left(-23^{\circ} \mathrm{C}\right)$ in cryovials. Following 24 -h exposition in the freezer, the samples were lyophilized in vacuum, weighted and then stored at $-23^{\circ} \mathrm{C}$ with silica-gel until protein analysis. Standard protein analysis was performed with Folin-Lawry techniques (El Alaoui et al. 1992). Calibration curve was plotted on the protein standard BSA SIGMA (stock solution $400 \mu \mathrm{g} \mathrm{ml}^{-1}$ ). Absorption level was measured at $500 \mathrm{~nm}$ wavelength with Shimadzu-UV-120-02 spectrophotometer, and a total of 58 samples were processed.

\section{Lipid analyses}

Copepods were sampled and sorted as described before for the protein analysis. Animals were placed into Petri dishes with cold filtered seawater and then transferred into cups on ice that had been thoroughly prewashed with chloroform. Copepods were placed in the cups, gently washed with cold distilled water, which was then removed with Kleenex tissue. The animals were then immediately preserved in $1 \mathrm{ml}$ of dichloromethane:methanol mixture (2:1, by vol.). Samples were stored at $-30^{\circ} \mathrm{C}$ until analysis. Lipids were extracted according to Folch et al. (1957). The fatty acid (FA) and alcohol compositions were determined using gas chromatography (Kattner and Fricke 1986). Briefly, lipids were hydrolyzed in methanol containing $3 \%$ concentrated sulphuric acid, and FAs were converted to methyl esters by trans-esterification at $80^{\circ} \mathrm{C}$ for $4 \mathrm{~h}$. FA methyl esters and free alcohols were then simultaneously analyzed with a gas liquid chromatograph $(\mathrm{HP} 6890 \mathrm{~N})$ on a $30 \mathrm{~m} \times 0.25 \mathrm{~mm}$ i.d. wall-coated open tubular column (film thickness: $0.25 \mu \mathrm{m}$; liquid phase: DB-FFAP) using temperature programming in accordance with standard techniques. FAs and alcohols were identified with standard mixtures and, if necessary, additional confirmation was carried out by GC-MS. The small amount of lipids was insufficient for lipid class analysis; thus, recalculations from FA and fatty alcohol (FAlc) analysis were used. Lipid amount was expressed as sum of FA and FAlc. The calculations given by Kattner and Fricke (1986) were used to obtain the percentage of WEs.

\section{Starvation experiments}

Series of experiments were performed with CIV and CV copepodits of Temora longicornis to investigate whether temperature and food availability have a significant effect on $\mathrm{CN}$ content and $\mathrm{C}: \mathrm{N}$ ratio. Elder copepodits (CIV) and premature $(\mathrm{CV})$ specimens were used to analyze possible reactions to a changing environment and the possibility of their survival under harsh environmental conditions. Experiments were performed in 2-12 Aug 2004, at the White Sea Biological Station. Copepodits (CIV and CV, from 13 to 


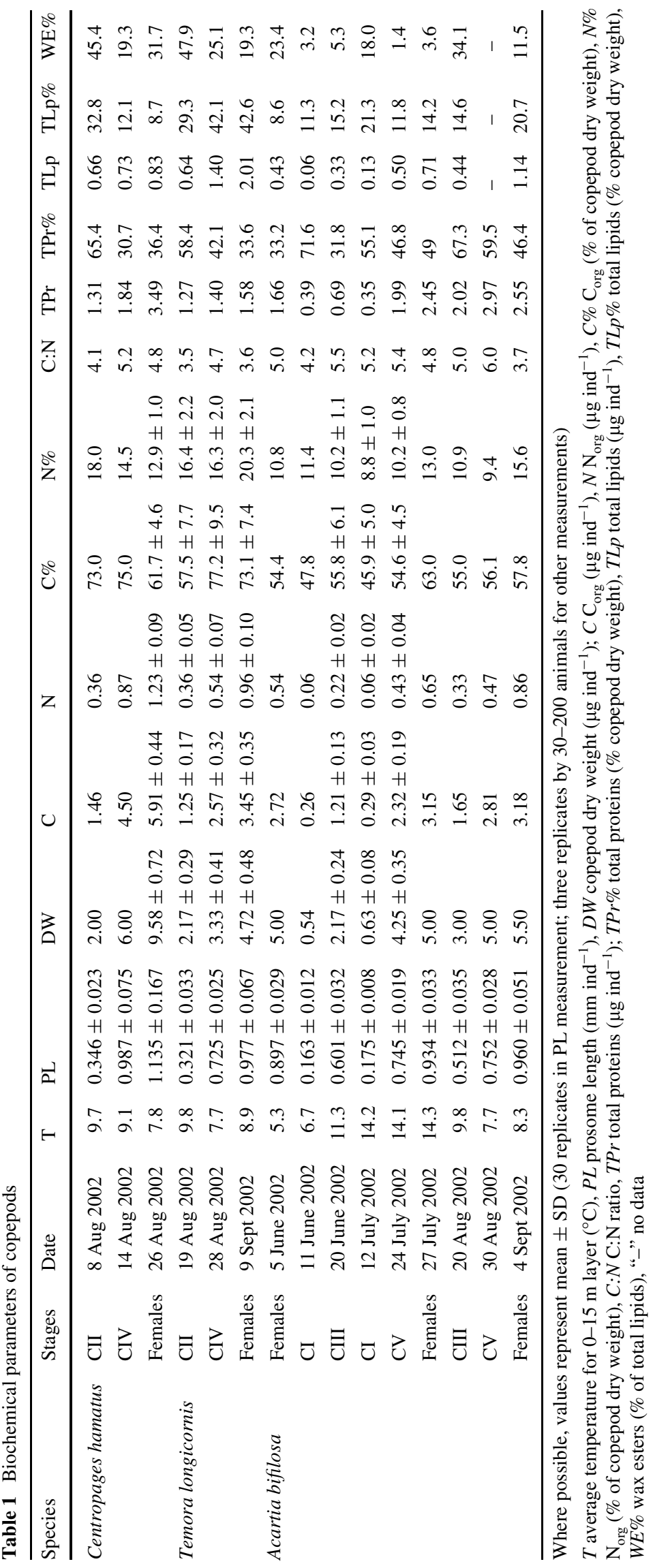


15 animals from each developmental stage) were placed in plastic jars (1,000 ml) for 2, 3, 4, 6, 8 and 10 days. The jars were exposed to changing light $(12 / 12 \mathrm{~h})$ on the plankton wheels with $2.0 \mathrm{rpm}$. Experiments were conducted at two temperatures $\left(+10\right.$ and $\left.+15^{\circ} \mathrm{C}\right)$ and with two different food conditions: (1) animals were placed in prescreened water $(1 \mu \mathrm{m})$ or (2) fed every day by adding of natural phytoplankton and microzooplankton $(<76 \mu \mathrm{m})$. Every day, the one-fourth of the water volume was replaced with fresh/ prescreened seawater at +10 or $+15^{\circ} \mathrm{C}$ according to the temperature in the experiment. Phytopigments (Chl. $a$, recalculated in organic C, PPC) and total organic carbon content of given natural food were measured every day, with means $\pm \mathrm{SD}$ of $36.2 \pm 4.2$ and $212.2 \pm 9.3 \mu \mathrm{g} 1^{-1}$, respectively, with no significant differences through the period of experiment. Experiments were performed in triplicates for each condition (day, temperature, food); thus, 72 jars on four plankton wheels were used. Once the experiment was completed, the animals were counted by developmental stage and then prepared for $\mathrm{CN}$ analysis as described before. Animals from each jar were placed onto one GF/C filter. As Temora longicornis is too small to measure $\mathrm{CN}$ for each individual copepodit, an average for the animals from one jar was measured. Dead animals were excluded from the analysis, since bacterial colonization of their carcasses (Tang 2005) may strongly affect the CN measurement results. The number of animals was also too low to perform lipid analysis.

\section{Statistics}

One-way ANOVA was applied to analyze the differences between species and stages in DW, PL, C and N. The "species" factor included three gradients (species). Our analysis included three groups of copepodit stages: (1) CI-CIII (young) copepodits, (2) CIV-CV (elder) copepodits and (3) females. Comparison between species was only performed for August data to exclude the effect of early generations (June, July) of Acartia bifilosa. Multiple linear regression analysis was applied to assess whether food and temperature conditions affect Acartia's female PL, DW and C content through the sampling season. Average organic $\mathrm{C}$ and phytopigment content in potential food and average temperature for $0-15 \mathrm{~m}$ through the investigation season (Martynova et al., unpublished) was used for the periods between females appearance. Dependence of average organic carbon content and $\mathrm{C}: \mathrm{N}$ ratio per animal on food availability and temperature during the starvation experiment with Temora longicornis was studied. Growth (\% of moult specimens) and death (\% of dead animals) indexes were recalculated for further comparison of age population structure. A one-way ANOVA analysis with additional implications of Tukey HSD post hoc test was applied to look for the differences in $\mathrm{C}, \mathrm{N}, \%$ moult and \% dead copepods between experiment treatments. Prior to the analysis, data were subjected to an angular transformation, which homogenized the variances in all the cases. The homogeneity of analysis has been tested by the Levene-test.

\section{Results}

Temperature and feeding conditions

Temperature throughout the study ranged from +1.5 to $+17.0^{\circ} \mathrm{C}$; salinity varied from 24.78 to 28.11 PSU. Organic carbon content (POC) ranged from 29.0 to $373.0 \mu \mathrm{g} \mathrm{l^{-1 }}$, while phytopigment concentration (Chl. $a$ ) reached up to $2.69 \mu \mathrm{g} 1^{-1}$.

General differences between species (August generations)

Dry weight of studied species exhibited a wide range in variability from 2.00 (Centropages hamatus, CII) to $9.58 \pm 0.72 \mu \mathrm{g}$ ind $^{-1}$ (the same species, females, Table 1). CI copepodits of Acartia were quite smaller ( $0.54 \mu \mathrm{g} \mathrm{DW}$ ind $^{-1}$, 12 July 2002), but the average DW across all the stages in total of this species compared to Temora and Centropages had no significant differences (ANOVA: $F=3.35 ; P=0.06$ ). Absolute organic carbon content reached up to $5.91 \pm 0.44 \mu \mathrm{g} \mathrm{DW}$ ind $^{-1}$ (Centropages females).

Relative $\mathrm{C}$ and $\mathrm{N}$ contents (\% DW) in Acartia bifilosa were $58.1 \pm 4.5 \%$ and $12.0 \pm 3.3 \%$, respectively, and was significantly lower when compared to the same parameters for Centropages hamatus $(69.9 \pm 7.2 \%$ and $15.1 \pm 2.6 \%$, respectively) and Temora longicornis $(69.3 \pm 10.4 \%$ and $17.6 \pm 2.3 \%$, respectively) (ANOVA: $F=13.86$ and $P<0.001$ for $\mathrm{C} ; F=36.56$ and $P<0.001$ for $\mathrm{N})$. Differences in relative $\mathrm{C}$ content between Temora and Centropages were insignificant (ANOVA: $F=0.02, P=0.89$ ); however, Temora had significantly higher relative $\mathrm{N}$ content compared to Centropages (ANOVA: $F=4.52$, $P<0.05)$. The $\mathrm{C}: \mathrm{N}$ ratio for $A$. bifilosa was the highest in three species (ANOVA: $F=16.22, P<0.001$ ) and averaged $5.0 \pm 0.6$, followed by Centropages $(4.7 \pm 0.6)$ and Temora (3.9 \pm 0.7$)$.

Total protein content reached up to $3.49 \mu \mathrm{g}^{-1}$ (Cen- $^{-1}$ tropages females, Table 1). Differences in average relative protein content $(\% \mathrm{DW})$ for all the stages of Centropages $(44 \pm 19 \%), \quad$ Temora $(45 \pm 13 \%)$ and A. bifilosa $(60 \pm 7 \%)$ was insignificant due to high variability (ANOVA: $F=1.68, P=0.25$ ).

Centropages and Acartia also had the lowest percentage of lipids (\%DW) of the three species (averaging $18 \pm 13 \%$ and $15 \pm 4 \%$, respectively) with great differences between developmental stages. Temora longicornis had significantly 
higher lipid content when compared to the other two species (average $38 \pm 7 \%$; ANOVA: $F=2.57, P<0.01$ ). Meanwhile, $C$. hamatus and T. longicornis had a comparatively higher relative WE content (\% from total lipids) and averaged $32 \pm 12 \%$ and $31 \pm 15 \%$, respectively, as opposed to A. bifilosa $(13 \pm 12 \%)$; even then, these differences were insignificant due to high data variability (ANOVA: $F=1.05, P=0.41)$.

Differences between developmental stages

(August generations)

Animals of different stages within the investigated species showed high variability of features studied. Developmental stage did not affect either relative organic $\mathrm{C}$ or $\mathrm{N}$ content within all investigated species (ANOVA: $F=0.56$, $P=0.59$ for $\mathrm{C} ; F=0.31, P=0.76$ for $\mathrm{N})$. The $\mathrm{C}: \mathrm{N}$ ratio was also independent of developmental stage (ANOVA: $F=2.54, P=0.15)$. However, copepod prosome length for all the species increased during the growth, as did the DW and organic carbon content (Table 1). Increasing PL significantly affected organic carbon content, which increased for all the copepods investigated (Fig. 1a). Regression model for biomass-length relationship was applied and revealed exponential increasing of organic $\mathrm{C}$ during copepod growth. Additionally, copepod organic $\mathrm{C}$ content correlated positively with their DW and could be described by linear regression (Fig. 1b).

Absolute protein and lipid content varied greatly and thus did not depend on developmental stage (ANOVA: $F=2.36, P=0.16$ for proteins; $F=1.48, P=0.30$ for lipids). Relative content of lipids and proteins (\%DW) showed the same tendency (ANOVA: $F=2.98, P=0.12$ for proteins; $F=0.12, P=0.89$ for lipids).

\section{Differences between generations (Acartia bifilosa)}

This species was investigated from June through September and animals from different generations were studied (Table 1). Copepod prosome length fluctuated in A. bifilosa females of different generations. Although the average PL increased by more than $10 \%$ during the season from $897 \pm 0.029$ to $960 \pm 0.051 \mu \mathrm{m}$, this increase was insignificant (ANOVA: $F=1.99, P=0.22$ ); a similar pattern was seen in DW and C content. Neither the increase of temperature nor the food concentration influenced PL, DW and $C$ changes (regression analysis: $P>0.1$ for all cases). Immature copepods did not show any significant seasonal patterns in PL, DW and C content. Acartia females' C:N ratio decreased through the season from 5.0 to 3.7 , as protein and $\mathrm{N}$ content were simultaneously increasing (Table 1). Absolute carbon content positively correlated with DW and PL (Fig. 2). Copepodits of different
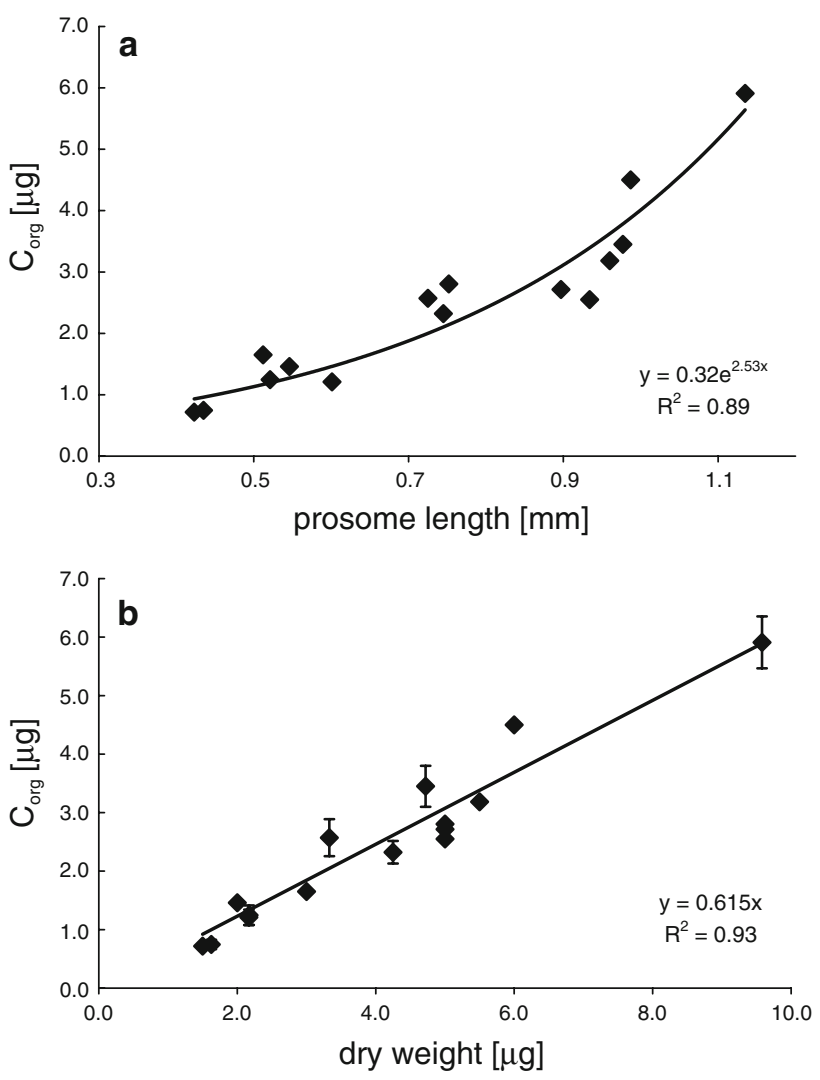

Fig. 1 Relationship between organic carbon content and (a) copepod prosome length and (b) dry weight, for all studied species in August. Regression equation and $R^{2}$ values are given for each curve

developmental stages of A. bifilosa had high variability of protein and lipid content. Absolute values for proteins ranged from $0.35 \mu \mathrm{g}$ ind $^{-1}$ (CIII) to $2.95 \mu \mathrm{g}$ ind $^{-1}$ (females, Table 1). The relative protein content (expressed as percent of DW) varied considerably more than doubling between CI and CIII copepodits, from 31.8 to $71.6 \%$. Animals of young (CI-CIII) copepodit stages of A. bifilosa had higher protein content, except for one case of CIII copepodits in June (31.8\%). A similar pattern was observed for June females that had already spawned. These females also exhibited extremely low lipid content (8.5\%). At the end of June, protein content for CIII of A. bifilosa was around $32 \%$, while in August the same parameter for similar developmental stages was twice as high $(67 \%)$. An analogous pattern was shown for the females: June animals had 33\% of protein from their DW, while July and September generations had nearly twice this (57 and 54\%, respectively). At the same time, lipid content for CI-CIII copepodits from different generations was about $15 \%$, while this parameter for females increased during the season four times from 8.5 to $39 \%$. There was no correlation between $\mathrm{C}$ content and lipid content $(r=0.29)$. Total absolute lipid content varied from 0.06 to $1.14 \mu \mathrm{g} \mathrm{ind}^{-1}$ (CI copepodits and females, respectively, Table 1). WE presence was minor for all the 

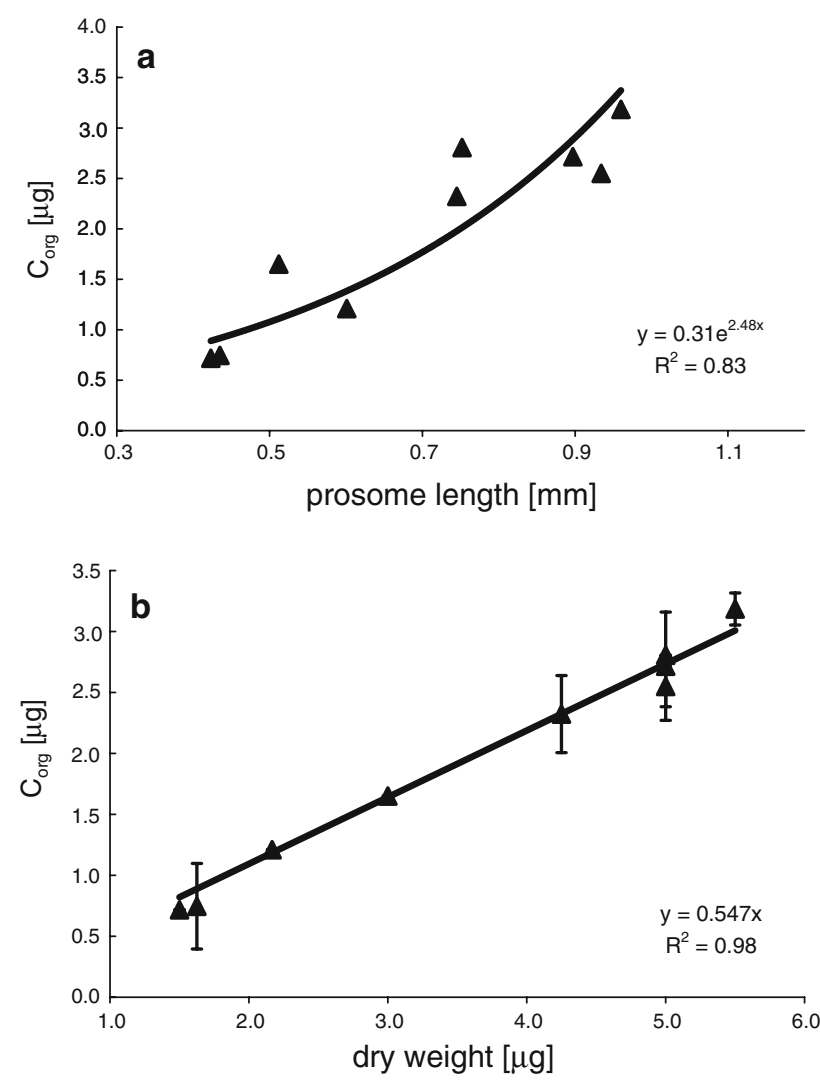

Fig. 2 Relationship between organic carbon content and (a) copepod prosome length and (b) dry weight, for Acartia bifilosa. Regression equation and $R^{2}$ values are given for each curve

developmental stages, with $1.4 \%$ being the lowest for $\mathrm{CV}$ copepodits at the end of July.

\section{Starvation experiments (Temora longicornis)}

Starvation experiments with Temora longicornis revealed strong differences in age structure for animals held in various food supplement conditions (Fig. 3). No significant differences were found for the age structure of copepodits exposed in various temperature conditions within the group of the same food supplement (ANOVA: $F=0.43$, $P=0.81$ ); however, food sufficiency was the crucial factor for death (Fig. 3) and molting (Fig. 4a) indexes (ANOVA: $F=18.86, P<0.001$; and $F=51.87, P<0.001$; respectively). Starved animals did reach mature stages in some exceptional minor cases (one to two copepodits). Average organic carbon per animal also differed between the various treatment groups. The organic carbon content significantly differed for starved and normally fed animals at the end of experiment (Tukey HSD: $d f=5.12, P<0.05$ ). At the beginning of the experiment, copepodits contained $2.8 \pm 0.3 \mu \mathrm{g} \mathrm{C}_{\text {ind }^{-1}}$; on the tenth day, fed specimens had $3.2 \pm 0.5 \mu \mathrm{g} \mathrm{C}_{\text {ind }^{-1}}$, while starved animals contained only $2.3 \pm 0.1 \mu \mathrm{g} \mathrm{C}^{-1}$ (Fig. $^{-1}$ ). However, the content of organic nitrogen did not change significantly (Fig. 4c), averaging $0.72 \pm 0.07$ and $0.63 \pm 0.07 \mu \mathrm{g} \mathrm{N}$ ind $^{-1}$ for fed and starved animals on the tenth day, respectively (Tukey HSD: $d f=0.99, P=0.65)$. C:N ratio averaged as $4.0 \pm 0.4$ for freshly taken animals (start of the experiment), $4.5 \pm 0.6$ for the animals with food supply and $3.6 \pm 0.3$ for starved animals, and differed significantly by the tenth day for animals with different food treatment (Tukey HSD: $d f=4.99, P<0.05$; Fig. 4d). No significant difference in $\mathrm{C}: \mathrm{N}$ ratio or organic nitrogen/carbon content was revealed for the copepodits that were exposed to various temperature conditions within the group of the same food supplement (ANOVA: $P>0.05$ for all cases).

\section{Discussion}

Copepod prosome length, DW and absolute organic carbon/ nitrogen content increased during the growth and maturation of copepod and were described in mathematical equations for numerous species (see, for review, Mauchline 1998). In general, relative organic carbon content depends on the copepod DW, as these two parameters are usually dependent on the body (or prosome) length; yet they may be quite variable even within one species (Carlotti et al. 2007). Our data for Acartia bifilosa, Centropages hamatus and Temora longicornis species, inhabiting the White Sea, show significant dependence of C on DW and DW on PL, supporting the results from previous investigations. As an example, Pastorinho et al. (2003) showed exponential regression between PL and C in Acartia tonsa, where biomass/length relationship was estimated as follows: $Y=0.15 \mathrm{e}^{3.04 x}$. Our data provided a similar relationship as $Y=0.32 \mathrm{e}^{2.53 x}$ for whole dataset and $Y=0.31 \mathrm{e}^{2.48 x}$ for Acartia bifilosa.

High latitude systems show well-pronounced dynamics of external factors and this affects seasonal changes in biochemical features of copepods, their feeding activity and finally their life cycles. In Arctic regions, marine copepods employ two major life cycle strategies to survive harsh winter conditions. Most of the species could be divided into two groups with different overwintering phase: (1) copepodit and (2) resting (latent) eggs (Steidinger and Walker 1984). The animals in the first (deep-water) group store lipids and use them during the winter period without or with minor food supplement, and are adapted to low temperatures, as, for example, some Calanus species do (Kosobokova 1999). The other type may form resting eggs instead of lipid stores and prefer coastal areas (e.g. some species of Acartia, Centropages, Temora and others; Lindley 1986, 1990; Engel 2005).

Three coastal-investigated species, inhabiting the White Sea, are considered to be independent from the Barents Sea 
Fig. 3 Temora longicornis. Age structure changes under experimental conditions. $X$-axis day of experiment, $Y$-axis $\%$ of population in the experimental vial

Fig. 4 Temora longicornis. Biochemical changes under experimental conditions. $X$-axis day of experiment; $Y$-axis (a) molt individuals, $\%$ of population in the experimental vial, $(b)$ average $\mathrm{C}_{\text {org }}$ content, $(c)$ average $\mathrm{N}_{\text {org }}$ content, $(d)$ average C:N ratio
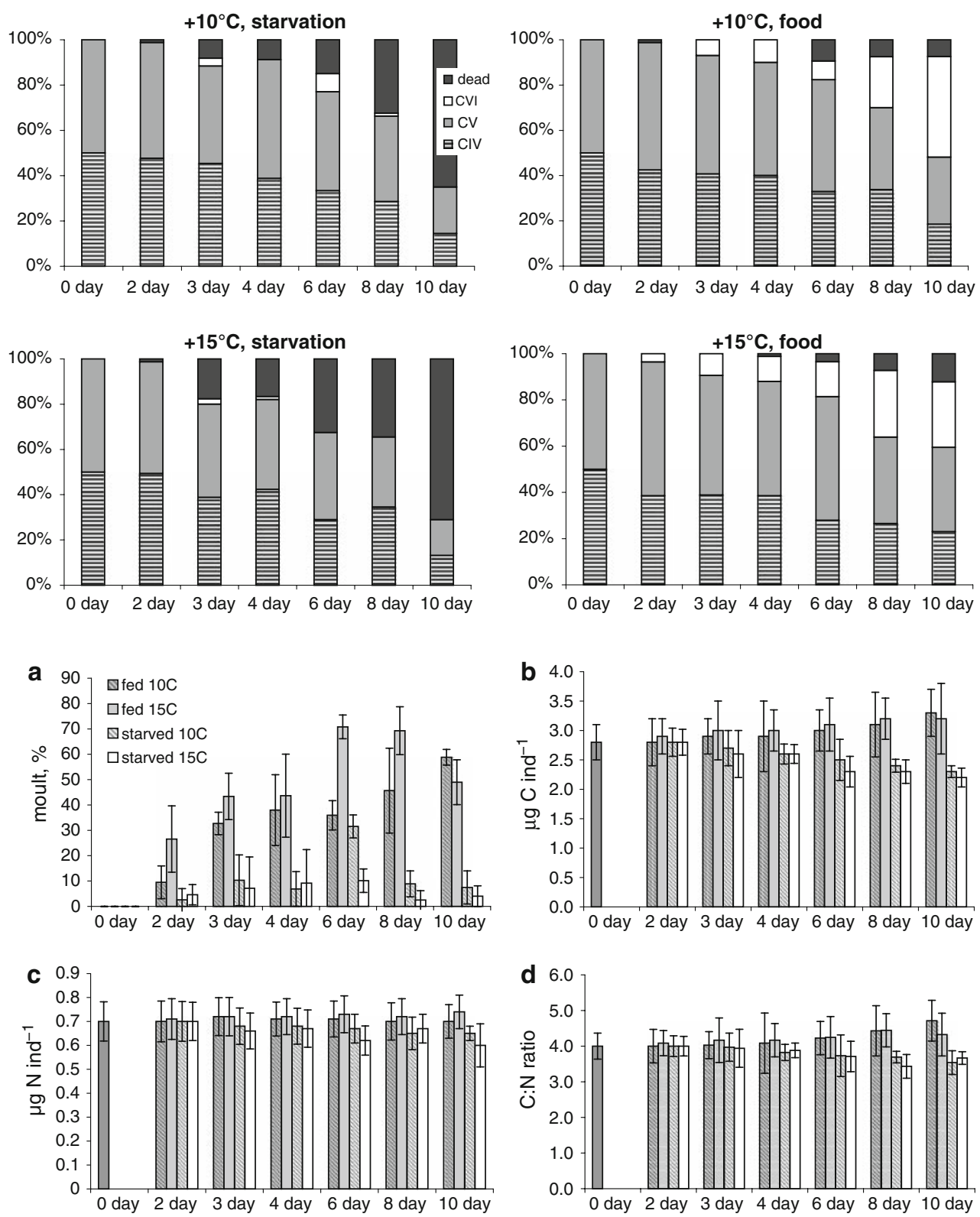

population. They are able to complete their life cycles and maintain themselves within the White Sea without advection of individuals from outside and form isolated populations (Pertsova and Pantyulin 2005). Centropages hamatus itself is one of the most abundant copepods on the continental shelf in the mid-Atlantic region of the western North Atlantic (Durbin and Kane 2007). This species is presented in the latitudinal range of $20^{\circ} \mathrm{S}-64^{\circ} \mathrm{N}$ and temperature range of $+3^{\circ}$ to $+20^{\circ} \mathrm{C}$ with optimal egg production at temperatures above $+10^{\circ} \mathrm{C}$ and increasing hatching success above $+15^{\circ} \mathrm{C}$ (CPR Survey Team 2004; Jo and Marcus 2004; Bonnet et al. 2007). In the North Sea, this species is present in plankton from March through September with three generations, has highest productivity in summer and forms resting eggs (Bonnet et al. 2007; Beaugrand et al.
2007). In the White Sea $\left(66^{\circ} \mathrm{N}\right)$, however, C. hamatus appears mostly in July and finishes with resting eggs at the end of September, producing from one to three generations within the temperature range +8 to $+16^{\circ} \mathrm{C}$ (Pertzova 1974; Usov and Zubakha 2004). Nevertheless, the short summer of less than 2 months in the White Sea (Berger et al. 2003) is sufficient for species success. In August, observed prosome length of $C$. hamatus females averages $1,135 \pm 167 \mu \mathrm{m}$, a size that is located in the upper part of the wide range $750-1,570 \mu \mathrm{m}$, reported for Atlantic population (Fransz et al. 1991).

Temora longicornis (alike $C$. hamatus) tends to populate warm coastal and shelf waters of North and Middle Atlantic, producing several generations and overwinters as resting eggs in northern areas (Gaard 1999; Dippner et al. 
2000; Licandro et al. 2001; Engel and Hirche 2004; Alheit et al. 2005; Aube et al. 2005; Devreker et al. 2005; Debes and Eliasen 2006; Durbin and Casas 2006; Kane and Prezioso 2008). In the North Sea, T. longicornis is present in plankton throughout the year, overwinters as copepodit stage in temperatures close to $0^{\circ} \mathrm{C}$ (Halsband and Hirche 2001). This species is observed in the Atlantic warm waters intruding Nordwestbanken (Northern Norway) and the Iceland shelf (Halvorsen and Tande 1999; Gislason and Astthorsson 2004). In summertime, in the White Sea, temperature conditions of the upper water layer, which is separated from cold waters at $30 \mathrm{~m}$ depth by a strong thermocline, are predominantly affected by dates of ice melting, air temperature and solar impact (Berger et al. 2003). Water temperatures may only remain above $+10^{\circ} \mathrm{C}$ for a period of less than 2 months, mostly in July and August (Babkov 1998; present study). Consequently, T. longicornis in the White Sea (as Centropages hamatus) only have a short time period of favorable conditions and as a result produces no more than three generations in summertime (Prygunkova 1974). The weight and length parameters of this species in the White Sea are in accordance with the data from other areas. Observed female length is $977 \pm 67 \mu \mathrm{m}$ and DW is $4.72 \pm 0.48 \mu \mathrm{g}$ and fit to values of $700-1,200 \mu \mathrm{m}$ length and of $10-40 \mu \mathrm{g}$ DW for T. longicornis from the Long Island Sound (USA) for a temperature field between 0 and $+22^{\circ} \mathrm{C}$ (Dam and Peterson 1991). The protein content for Temora varied between 52.4 and $57.6 \%$ of DW as observed by Evjemo et al. (2003) and 31-54\% for a Temora-dominated zooplankton community (Helland et al. 2003). In the present study, this parameter showed the same span of $33.6-58.4 \%$. This may be an indication that the short summer period is sufficient to produce at least one generation of T. longicornis in the White Sea successfully, within the given narrow temperature span. Furthermore, in the White Sea, Temora strictly overwinters only as resting eggs, which could be an effect of ice covering for long period up to 6 months per year (Babkov 1998).

For Acartia bifilosa, much less is known compared to the other species and the few published studies are quite old and even contradictory. Acartia bifilosa is found in Middle and North Atlantic (Castro-Longoria and Williams 1999; Vieira et al. 2003), in the Baltic Sea (Tanskanen 1994; Werner and Auel 2004) and in the disconnected area in the Yellow Sea and the Bohai Sea (Yoon et al. 1998; Li et al. 2003). In the White Sea, Acartia bifilosa species is present in zooplankton communities longer throughout the year than Centropages and Temora (Martynova et al. unpublished; present study), produces both subitaneous and resting eggs and has even been observed overwintering under the ice as copepodits in small shallow inlets (Kutcheva, personal communication). The latter was also reported for Baltic Sea by Werner and Auel (2004), where, despite low temperatures, this copepod continued growth and development below the ice, doubling in numbers (mainly CI, CII) during the third week of March. However, the most successful hatching of subitaneous eggs was observed for this species in the range of +10.0 to $+15.0^{\circ} \mathrm{C}$ (Castro-Longoria and Williams 1999). Acartia bifilosa females in the White Sea are significantly bigger than those observed in other areas, with prosome length $(868-1,011 \mu \mathrm{m})$ nearly twice as long at +5.3 to $+14.3^{\circ} \mathrm{C}$ (present study) compared to that of the same species $(518-714 \mu \mathrm{m})$ in the Yellow Sea at $+17 \pm 1^{\circ} \mathrm{C}$ (Yoon et al. 1998). In the northern Baltic, females are observed all the year round, grow up to $880 \mu \mathrm{m}$ PL and contain up to $1.056 \mu \mathrm{g} \mathrm{C}$ (Tanskanen 1994). As the northern Baltic, like the White Sea, is characterized by lower salinity compared to oceanic values (Flinkman et al. 1998), we consider that the White Sea population of Acartia bifilosa exhibits similarity to the northern Baltic population, which nicely coordinates with the Baltic origin of this species in the White Sea about 6,000 years ago (Pertsova and Pantyulin 2005). In Southampton Waters, A. bifilosa prefers a temperature span of +5.0 to $+12.0^{\circ} \mathrm{C}$ and is observed from January till June, producing both diapausing and subitaneous eggs (Castro-Longoria and Williams 1999). The disappearance of A. bifilosa in winter, in the latter case, is connected with increasing temperature, and this species has been reported as winter/spring crustacean species, while in the White Sea, evanescence of most of population is usually linked with water temperature decreasing in autumn (Prygunkova 1974; Berger et al. 2003).

The major factors, usually discussed as controlling the seasonal dynamics of investigated species in different regions of North Atlantic, are restricted temperature span and food sufficiency (Calbet and Agusti 1999; Halsband and Hirche 2001; Halsband-Lenk et al. 2002, 2004; Castellani and Altunbas 2006; Bonnet et al. 2007; Beaugrand et al. 2007; Durbin and Kane 2007). The same parameters also may have a strong effect on copepod body length, DW and organic $\mathrm{C}$ content, and such a phenomenon is well known for species with several generations through the productive season, e.g. Centropages, Temora and Acartia (Weisse 1983; Dam and Peterson 1991; Cataletto and Fonda Umani 1994; Gaudy et al. 1996; Halsband and Hirche 2001). The general trend is for a larger final body size at colder temperatures. As an example, Dam and Peterson (1991) observed a negative effect of increasing temperature on body size for Temora longicornis female PL, but they discuss this as primarily due to decreasing food availability affected by temperature changes. Therefore, lack of food had a particular greater impact in PL changes. In contrast, organic carbon content of Acartia tonsa females varies from 1.29 to $2.20 \mu \mathrm{g} \mathrm{ind}^{-1}$ and depends positively on the water temperature in the wide range from +5 to $+17^{\circ} \mathrm{C}$ (Gaudy et al. 1996). Yet, neither water temperature nor 
observed natural food concentration affected prosome length, DW or organic C content of Acartia bifilosa in the White Sea. A slight insignificant increase in these parameters was observed from June to August and had no relationships with food concentration both in total organic carbon and Chl. $a$.

To continue the discussion on the impact of temperature and food on species biology, one must consider growth rates and reproduction success. Egg production rates for Centropages tenuiremis from Xiamen waters (China) increased with seawater temperature and Chl. $a$ concentration, but after the latter reached a maximum, no significant relationship was found (Wu et al. 2007). Conversely, Centropages typicus developmental rate is governed less by food quality and quantity than by growth rate with high weight variability (Carlotti et al. 2007), and finally, in the north-west Mediterranean, Centropages typicus and Temora stylifera egg production rate does not even depend on food concentration (Halsband-Lenk et al. 2001), nor was a relationship found between Chl. $a$ and reproductive success in Temora longicornis (Arendt et al. 2005). Some studies reported higher importance of food quality over quantity as a major factor influencing changes in abundance and biochemical features of studied species (KozlowskySuzuki et al. 2006; Gaudy and Thibault-Botha 2007). Here, we conclude that the observed food concentrations in the White Sea are sufficient for Acartia bifilosa to maintain species prosome length; however, further investigations on egg production rates as a function of the seasonal food spectra are essential. In addition, the wide variability of biochemical features demonstrated in our study may also be related to genetic factors of the species involved. For example, the RNA variability of Acartia bifilosa from the Baltic Sea was positively correlated to PL, egg production rate and temperature span but not to spatial origin of the species (Holmborn and Gorokhova 2008).

Seasonal differences and starvation impact on protein and lipid content may bring new insights to this discussion. Carlotti et al. (2007) showed that the length/weight relationship in Centropages typicus is very variable, and the authors argue for more investigations on the seasonal changes in biochemical composition. Protein and lipid contents are biochemical features that could be used to describe seasonal and ontogenetical processes. Great seasonal differences in observed parameters for Acartia bifilosa in the White Sea are, at first glance, more likely connected with the animal's physiologic state. The females of the first generation (June) contained low protein and lipid levels, compared to the summer generation (July), which had much higher protein levels while lipid content remained relatively low. By the end of summer, protein content remained constant, but lipid content increased about threefold. We tend to link low lipid and protein contents of the June generation to the fact that most of females sampled in June had already spawned and are visually highly transparent. Yet, the C:N ratio was about 5 , but the relative amount of $\mathrm{C}$ and $\mathrm{N}$ was lower when compared to females of the other generations. We suggest that their body weight was composed mainly of exuviaes, which consist mostly of carbohydrates (chitin) and may explain both the high C:N ratio and low amount of proteins and lipids (Bamstedt 1986). Females of the summer generation had high protein content and ripe ovaries with eggs ready to be spawned. Females sampled at the end of August had no visible ovaries, but the high protein content marked their readiness for the first stage of breeding. This premise is supported by low $\mathrm{C}: \mathrm{N}$ ratio, which may be used as marker of rich protein, DNA and amino acid content (Postel et al. 2001). There are several dissimilarities in the biochemical indices for immature stages of A. bifilosa that must be discussed. Acartia CIII copepodits from different generations had different protein contents. For the end of June species total protein content was low, averaging about $32 \%$ of DW, whereas copepods from the August generation had a more than twofold increase in protein $(67 \%)$, yet lipid content was almost the same (about $15 \%$ ) and the C:N ratio was high (about 5). We cannot conclusively state the reasons for such a pattern, but a different physiological ratio of analyzed animals could be a possible explanation. The protein content may be rather high because of stage changes; CIII specimens caught at the end of June were just molting from CII stage, while animals in August were preparing to become CIV copepodits.

Lipid content itself and lipid composition may explain some life cycle strategy peculiarities. The mechanisms of lipid biosynthesis and storage for the Arctic species are well described (Kattner and Hagen 1995; Albers et al. 1996; Falk-Petersen et al. 1999; Lee et al. 2006), but nearly nothing is known about boreal species that inhabit high latitudes. It is assumed that tropical and temperate coastal copepods, which form resting eggs, do not need any additional large energy (lipid) reserves, since they finish their life cycles without long winter starvation. Scarce publications on single species starvation experiments, however, show quick loss of lipids for $T$. longicornis, while species such as Pseudocalanus elongatus survive in filtered water nearly twice as long as first species (Evjemo et al. 2003; Koski and Breteler 2003). The present investigation expects that Temora tends to lose only lipid reserves, keeping protein content intact. Since no measurements of lipid/protein content were performed, we assume that $\mathrm{CN}$ content dynamics and $\mathrm{C}: \mathrm{N}$ ratio may also be used as an indirect indicator of protein/lipid content (Postel et al. 2001). It is apparent that food sufficiency is a crucial factor in the present study, while temperature has no significant effect on molting and survival. Since increase in temperature increases metabolic rates in warm-water copepods, the food 
need increases at the higher temperatures (Ianora 1998; Melão et al. 2004; Pu et al. 2004). This effect could have been visible at intermediate food levels, although it is not evident at starvation or food saturation. Even after 10 days of total starvation, about one-third of Temora population still remained alive. The C:N ratio for starved specimens decreased significantly, but stayed relatively high (3.9 on average). Since under food absence, $\mathrm{C}$ content decreased significantly while $\mathrm{N}$ content was conserved, we postulate that under starvation elder specimens of Temora longicornis preferentially use lipids. Mature females of Temora longicornis in the North Sea (off Helgoland) show a dramatic decrease in egg and pellet production ratio, proteolytic enzyme and citrate synthase activities under starvation conditions and is highly dependent on the food supply, especially on the detrital and animal-based diet, in this region (Kreibich et al. 2008). Hence, we propose further lipid analysis for the White Sea population to understand whether the remaining lipids contain storage or only structural molecules, followed by respiration rate estimations to establish energy traits (Thor 2002).

We noticed obvious dissimilarities in WE content for Acartia bifilosa specimens of different stages and generations, as well as for Temora and Centropages species. Besides lipid content, the percentage of WEs is an important index of copepod physiological state (Cripps and Hill 1998; Stottrup et al. 1999; Helland et al. 2003). WEs are storage lipids, usually used during the overwintering or during other conditions with low food concentrations (Ward et al. 1996). Usually, WEs are found in species that have an overwintering copepodit stage. Such copepods in the White Sea are predominantly herbivorous Arctic species like Calanus glacialis and Pseudocalanus minutus. Tande and Henderson (1988) described WE in CIII copepods of $C$. glacialis in the Barents Sea and found that WE content increased during maturation. Copepods inhabiting temperate areas (e.g. Centropagidae in our case) are supposed to have low storage lipid content (Lee 1975b; McKinnon et al. 2003), and we did not find any data on the presence of WE in copepods of such species. Nevertheless, our findings of high WE content in young and old stages of boreal $T$. longicornis and $C$. hamatus may have the same biological cause as for Arctic species. When WE are found in boreal species, this may be explained as a physiological adaptation of copepods with short life cycles due to rapidly changing food conditions. During late August, boreal species begin to leave the plankton and we suggest that the observed high WE content may indicate preparation of the animals for possible starvation and, in this case, the ability to finish maturation and the reproductive phase of their life cycle. In contrast, WE content was minimal for all the developmental stages of the more ecologically flexible A. bifilosa with the lowest value of $1.4 \%$ for $\mathrm{CV}$ copepodits at the end of July. Sufficient food availability and optimal water temperature, creating perfect growing conditions for the last stage, could present a possible explanation for low WE content. Moreover, Acartia species in the White Sea has a wider temperature range for breeding (Usov and Zubakha 2004). This means that, in the summer season, given a wide temperature tolerance and sufficient food, Acartia does not need to form such energy molecules as WE. The question of whether Acartia can use triacylglycerols for possible overwintering as does the Antarctic species Calanus propinquus (Hagen and Auel 2001) still remains open.

In conclusion, we are stating dissimilitude of some biology aspects of Acartia bifilosa, Centropages hamatus and Temora longicornis in the White Sea compared to the same species at lower latitudes. These species comprise the isolated White Sea population (Pertsova and Pantyulin 2005), have delayed reproduction period (Prygunkova 1974) and differ in some biochemical features (present study). The isolation of the White Sea in last postglacial period for last 6,000 years and harsh environmental conditions are usually named as the mechanism for the first two phenomena (Berger et al. 2003). We suggest that this complex also evolved some special biochemical features (especially the presence of WEs) of these species. We suggest species-specific ability to resist long starvation using lipid reserves, which might be important in success determination of copepod populations (Koski and Breteler 2003). Consequently, high variability in $\mathrm{C}: \mathrm{N}$ ratio in the observed range of 3.7-6.0 may be explained as a result of limiting nutrients for certain species, both algal and protozoan as food source, which affects reproduction and thus the physiological state (Postel et al. 2001; Pertola et al. 2002; Ianora et al. 2007; Souissi et al. 2008). Wider optima for A. bifilosa may be a result of lower food quality demands, when Acartia displayed an even less selective behavior comparing to omnivorous Centropages and Temora species (Kozlowsky-Suzuki et al. 2006). We did not find any limitations of temperature or food quantity for these copepods when comparing them to the same species from other areas. Therefore, we propose food quality demands and long ice coverage as possible factors limiting early development of species in spring. The deficiency in food quality may be an important factor of autumn species disappearance, which is a topic for future studies.

Acknowledgments We are cordially thankful to Dr. Alexey Sukhotin, Dr. Evgeny Pakhomov and Elizabeth Sweet for their valuable advice and three anonymous reviewers for helpful comments, which greatly improved the previous version. Special thanks for B. Meyer, C. Lorenzen and H. Schwarz for their technical support in biochemical analysis at the Alfred-Wegener-Institute for Polar and Marine 
Researches (AWI) in Bremerhaven. The investigation was supported by the German Association of Academical Exchange, DAAD (fellowship MBFOKU\#A/2403) and the Russian Foundation for Basic Researches (RFBR grants N05-04-49316-a and N07-04-10165-k).

Open Access This article is distributed under the terms of the Creative Commons Attribution Noncommercial License which permits any noncommercial use, distribution, and reproduction in any medium, provided the original author(s) and source are credited.

\section{References}

Albers CS, Kattner G, Hagen W (1996) The composition of wax esters, tryacilglycerols and phospholipids in Arctic and Antarctic copepods: evidence of energetic adaptations. Mar Chem 55:347-358

Alheit J, Mollmann C, Dutz J, Kornilovs G, Loewe P, Mohrholz V, Wasmund N (2005) Synchronous ecological regime shifts in the Central Baltic and the North Sea in the late 1980s. ICES J Mar Sci 62:1205-1215

Anger K (2001) The biology of decapoda larvae. In: Vonk R (ed) Crustacean issues, vol 14. A. A. Balkema Publishers, Lisse

Arendt KE, Jonasdottir SH, Hansen PJ, Gartner S (2005) Effects of dietary fatty acids on the reproductive success of the calanoid copepod Temora longicornis. Mar Biol 146:513-530

Aube CI, Locke A, Klassen GJ (2005) Zooplankton communities of a dammed estuary in the Bay of Fundy, Canada. Hydrobiologia 548:127-139

Auel H, Hagen W (2005) Body mass and lipid dynamics of Arctic and Antarctic deep-sea copepods (Calanoida, Paraeuchaeta): ontogenetic and seasonal trends. Deep Sea Res Part I Oceanogr Res Pap 52:1272-1283

Babkov AI (1998) Hydrology of the White Sea. Zoological Institute RAS, St Petersburg, p 96 (in Russian)

Bamstedt U (1986) Chemical composition and energy content. In: Corner EDS, O'Hara SCM (eds) The biological chemistry of marine copepods. Clarendon Press, Oxford

Bathmann UV, Makarov RR, Spiridonov VA, Rohardt G (1993) Winter distribution and overwintering strategies of the Antarctic copepod species Calanoides acutus, Rhincalanus gigas and Calanus propinquus (Crustacea Calanoida) in the Weddell Sea. Polar Biol 13:333-346

Beaugrand G, Lindley JA, Helaouet P, Bonnet D (2007) Macroecological study of Centropages typicus in the North Atlantic Ocean. Prog Oceanogr 72:259-273

Berger VJa, Naumov AD, Usov N, Zubaha M, Smolyar I, Tatusko R, Levitus S (2003) 36-year time series (1963-1998) of zooplankton, salinity and temperature in the White Sea, NOAA Atlas NESDIS 57. US Government Printing Office, Washington, DC

Bonnet D, Harris R, Lopez-Urrutia A, Halsband-Lenk C, Greve W, Valdes L, Hirche H-J, Engel M, Alvarez-Ossorio MT, Wiltshire K (2007) Comparative seasonal dynamics of Centropages typicus at seven coastal monitoring stations in the North Sea, English Channel and Bay of Biscay. Prog Oceanogr 72:233-248

Calbet A, Agusti S (1999) Latitudinal changes of copepod egg production rates in Atlantic waters: temperature and food availability as the main driving factors. Mar Ecol Prog Ser 181:155-162

Carlotti F, Bonnet D, Halsband-Lenk C (2007) Development and growth rates of Centropages typicus. Prog Oceanogr 72:164194

Castellani C, Altunbas Y (2006) Factors controlling the temporal dynamics of egg production in the copepod Temora longicornis. Mar Ecol Prog Ser 308:143-153

Castro-Longoria E, Williams JA (1999) The production of subitaneous and diapause eggs: a reproductive strategy for Acartia bifilosa
(Copepoda: Calanoida) in Southampton Water, UK. J Plankton Res 21:65-84

Cataletto B, Fonda Umani S (1994) Seasonal variations in carbon and nitrogen content of Acartia clausi (Copepoda, Calanoida) in the Gulf of Trieste (Northern Adriatic Sea). Hydrobiologia 292/ 293:283-288

Childress JJ, Nygaard M (1974) Chemical composition and buoyancy of midwater crustaceans as function of depth of occurrence off Southern California. Mar Biol 27:225-238

CPR Survey Team (2004) Continuous plankton records: plankton atlas of the North Atlantic Ocean (1958-1999). II. Biogeographical charts. Marine Ecology Progress Series, Supplement, pp 11-75

Cripps GC, Hill HJ (1998) Changes in lipid composition of copepods and Euphausia superba assosiated with diet and environmental conditions in the marginal ice zone, Bellinshausen Sea, Antarctica. Deep Sea Res Part I Oceanogr Res Pap 45:1357-1381

Dam HG, Peterson WT (1991) In situ feeding behaviour of the copepod Temora longicornis: effects of seasonal change in chlorophyll size fractions and female size. Mar Ecol Prog Ser 71:113-123

Debes HH, Eliasen K (2006) Seasonal abundance, reproduction and development of four key copepod species on the Faroe Shelf. Mar Biol Res 2:249-259

Devreker D, Souissi S, Seuront L (2005) Effects of chlorophyll concentration and temperature variation on the reproduction and survival of Temora longicornis (Copepoda, Calanoida) in the Eastern English Channel. J Exp Mar Biol Ecol 318:145-162

Dippner JW, Kornilovs G, Sidrevics L (2000) Long-term variability of mesozooplankton in the Central Baltic Sea. J Mar Syst 25:23-31

Durbin EG, Casas MC (2006) Abundance and spatial distribution of copepods on Georges Bank during the winter/spring period. Deep Sea Res Part II Top Stud Oceanogr 53:2537-2569

Durbin E, Kane J (2007) Seasonal and spatial dynamics of Centropages typicus and $C$. hamatus in the western North Atlantic. Prog Oceanogr 72:249-258

El Alaoui S, Mian S, Lawry J, Quash G, Griffin M (1992) Protein measurement with the Folin phenol reagent. J Biol Chem 193:265275

Engel M (2005) Calanoid copepod resting eggs—a safeguard against adverse environmental conditions in the German Bight and the Kara Sea? Ber Polarforsch Meeresforsch 508:108

Engel M, Hirche HJ (2004) Seasonal variability and inter-specific differences in hatching of calanoid copepod resting eggs from sediments of the German Bight (North Sea). J Plankton Res 26:10831093

Evjemo JO, Reitan KI, Olsen Y (2003) Copepods as live food organisms in the larval rearing of halibut larvae (Hippoglossus hippoglossus L.) with special emphasis on the nutritional value. Aquaculture 227:191-210

Falk-Petersen S, Pedersen G, Kwasniewski S, Hegseth EN, Hop H (1999) Spatial distribution and life-cycle timing of zooplankton in the Marginal Ice Zone of the Barents Sea during the summer melt season in 1995. J Plankton Res 21:1249-1264

Flinkman J, Aro E, Vuorinen I, Viitasalo M (1998) Changes in northern Baltic zooplankton and herring nutrition from 1980s to 1990s: top-down and bottom-up processes at work. Mar Ecol Prog Ser 165:127-136

Folch J, Lees M, Sloane-Stanley GH (1957) A simple method for isolating total lipids from animal tissues. J Biol Chem 226:497-509

Fransz HG, Colebrook JM, Gamble JC, Krause M (1991) The zooplankton of the North Sea. Neth J Sea Res 28:1-52

Gaard E (1999) The zooplankton community structure in relation to its biological and physical environment on the Faroe Shelf, 19891997. J Plankton Res 21:1133-1152

Gaudy R, Thibault-Botha D (2007) Metabolism of Centropages species in the Mediterranean Sea and the North Atlantic Ocean. Prog Oceanogr 72:151-163 
Gaudy R, Pagano M, Cervetto G, Saint-Jean L, Verriopoulos G, Beker B (1996) Short term variations in feeding and metabolism of Acartia tonsa (pelagic copepod) in the Berre Lagoon (France). Oceanol Acta 19:635-645

Gislason A, Astthorsson OS (2004) Distribution patterns of zooplankton communities around Iceland in spring. Sarsia 89:467-477

Hagen W, Auel H (2001) Seasonal adaptations and the role of lipids in oceanic zooplankton. Zool Anal Complex Syst 104:313326

Halsband C, Hirche HJ (2001) Reproductive cycles of dominant calanoid copepods in the North Sea. Mar Ecol Prog Ser 209:219-229

Halsband-Lenk C, Nival S, Carlotti F, Hirche HJ (2001) Seasonal cycles of egg production of two planktonic copepods, Centropages typicus and Temora stylifera, in the North-Western Mediterranean Sea. J Plankton Res 23:597-609

Halsband-Lenk C, Hirche HJ, Carlotti F (2002) Temperature impact on reproduction and development of congener copepod populations. J Exp Mar Biol Ecol 271:121-153

Halsband-Lenk C, Carlotti F, Greve W (2004) Life-history strategies of calanoid congeners under two different climate regimes: a comparison. ICES J Mar Sci 61:709-720

Halvorsen E, Tande KS (1999) Physical and biological factors influencing the seasonal variation in distribution of zooplankton across the shelf at Nordvestbanken, Northern Norway, 1994. Sarsia 84:279-292

Harris RP, Wiebe PH, Lenz J, Skjoldal HR, Huntley M (eds) (2000) ICES zooplankton methodology manual. Academic Press, London, p 684

Helland S, Terjesen BF, Berg L (2003) Free amino acid and protein content in the planktonic copepod Temora longicornis compared to Artemia franciscana. Aquaculture 215:213-228

Hirst AG, Lampitt RS (1998) Towards a global model of in situ weight-specific growth in marine planktonic copepods. Mar Biol 132:247-257

Holmborn T, Gorokhova E (2008) Relationships between RNA content and egg production rate in Acartia bifilosa (Copepoda, Calanoida) of different spatial and temporal origin. Mar Biol 153:483491

Hygum BH, Rey C, Hansen BW, Tande K (2000) Importance of food quantity to structural growth rate and neutral lipid reserves accumulated in Calanus finmarchicus. Mar Biol 136:1057-1073

Ianora A (1998) Copepod life history traits in subtemperate regions. J Mar Syst 15:337-349

Ianora A, Miralto A, Halsband-Lenk C (2007) Reproduction, hatching success, and early naupliar survival in Centropages typicus. Prog Oceanogr 72:195-213

Jo S-G, Marcus NH (2004) The effect of temperature and duration of incubation on the hatching of diapause eggs of Centropages hamatus (Lilljeborg) (Copepoda, Calanoida). Aquac Res 35:432-435

Kane J, Prezioso J (2008) Distribution and multi-annual abundance trends of the copepod Temora longicornis in the US Northeast Shelf Ecosystem. J Plankton Res (in press). doi:10.1093/plankt/ fbn026

Kattner G, Fricke HSG (1986) Simple gas-liquid chromatographic method for the simultaneous determination of fatty acids and alcohols in wax esters of marine organisms. J Chromatogr 361:263-268

Kattner G, Hagen W (1995) Polar herbivorous copepods-different pathways in lipid biosynthesis. ICES J Mar Sci 52:329-335

Koski M, Breteler WCMK (2003) Influence of diet on copepod survival in the laboratory. Mar Ecol Prog Ser 264:73-82

Koski M, Breteler WCMK, Schogt N (1998) Effect of food quality on rate of growth and development of the pelagic copepod Pseudocalanus elongatus (Copepoda: Calanoida). Mar Ecol Prog Ser 170:169-187
Kosobokova KN (1999) The reproductive cycle and life history of the Arctic copepod Calanus glacialis in the White Sea. Polar Biol 22:254-263

Kozlowsky-Suzuki B, Carlsson P, Ruhl A, Graneli E (2006) Food selectivity and grazing impact on toxic Dinophysis spp. by copepods feeding on natural plankton assemblages. Harmful Algae 5:57-68

Kreibich T, Saborowski R, Hagen W, Niehoff B (2008) Short-term variation of nutritive and metabolic parameters in Temora longicornis females (Crustacea, Copepoda) as a response to diet shift and starvation. Helgol Mar Res 62(3):241-249

Lee RF (1975a) Lipids of Arctic zooplankton. Comp Biochem Physiol B Biochem Mol Biol 51:263-266

Lee RF (1975b) Lipids in the mesopelagic copepod, Gaussia princeps. Wax ester utilization during starvation. Comp Biochem Physiol B Biochem Mol Biol 52:265-268

Lee RF, Hagen W, Kattner G (2006) Lipid storage in marine zooplankton. Mar Ecol Prog Ser 307:273-306

Li CL, Wang R, Sun S (2003) Grazing impact of copepods on phytoplankton in the Bohai Sea. Estuar Coast Shelf Sci 58:487-498

Licandro P, Conversi A, Ibanez F, Jossi J (2001) Time series analysis of interrupted long-term data set (1961-1991) of zooplankton abundance in Gulf of Maine (Northern Atlantic, the USA). Oceanol Acta 24:453-466

Lindley JA (1986) Dormant eggs of calanoid copepods in sea-bed sediments of the English Channel and southern North Sea. J Plankton Res 8:399-400

Lindley JA (1990) Distribution of overwintering calanoid copepod eggs in sea-bed sediments around southern Britain. Mar Biol 104:209-217

Mauchline J (1998) Biology of Calanoid copepods. Advances in Marine Biology. The Scottish Association for Marine Science, UK

McKinnon AD, Duggan S, Nichols PD, Rimmer MA, Semmens G, Robino B (2003) The potential of tropical paracalanid copepods as live feeds in aquaculture. Aquaculture 179:1-18

Melão MGG, Rocha O (2004) Life history, biomass and production of two planktonic cyclopoid copepods in a shallow subtropical reservoir. J Plankton Res 26(8):909-923

Nanton DA, Castel J (1999) The effect of temperature and dietary fatty acids on the fatty acid composition of harpacticoid copepods, for use as a live food for marine fish larvae. Aquaculture 175:167181

Pastorinho R, Vieira L, Ré P, Pereira M, Bacelar-Nicolau P, Morgado F, Marques JC, Azeiteiro U (2003) Distribution, production, histology and histochemistry in Acartia tonsa (Copepoda: Calanoida) as means for life history determination in a temperate estuary (Mondego estuary, Portugal). Acta Oecol 24:S259-S273

Pertola S, Koski M, Viitasalo M (2002) Stoichiometry of mesozooplankton in N- and P-limited areas of the Baltic Sea. Mar Biol 140:425-434

Pertzova NM (1967) Average mass and sizes of abundant zooplankton species in the White Sea (Srednie vesa i razmery massovykh vidov zooplanktona Belogo morya). Oceanology 7:309-313 (in Russian with English abstract)

Pertzova NM (1974) Life cycle and ecology of warm-water copepod Centropages hamatus in the White Sea (Zhiznennyi zicl i ecologya teplovodnoj kopepody Centropages hamatus v Belom more). Zoologicheskiy zhurnal 53:1013-1022 (in Russian with English abstract)

Pertzova NM, Pantyulin AN (2005) Interrelationships between copepods (Copepoda, Calanoida) of the White and Barents seas and mechanisms of the independence of the White Sea population. Zool Zhurnal 84:948-956

Postel L, Fock H, Hagen W (2000) Biomass and abundance. In: Harris RP, Wiebe PH, Lenz J, Skjoldal HR, Huntley M (eds) ICES 
zooplankton methodology manual. Academic Press, London, pp 83-192

Prygunkova RV (1974) Some patterns of seasonal succession of zooplankton in Chupa Inlet, the White Sea (Nekotorye osobennosti sezonnogo razvitiya zooplanktona guby Chupa Belogo morya). Seasonal developments in White and Barents Seas (Sezonnye yavlenija v zhizni Belogo i Batrentsego morey). Nauka, Leningrad, pp 4-55 (in Russian)

Pu X-M, Sun S, Yang B, Ji P, Zhang Y-S, Zhang F (2004) The combined effects of temperature and food supply on Calanus sinicus in the southern Yellow Sea in summer. J Plankton Res 26(9): 1049-1057

Smetacek V, Hendrikson P (1979) Composition of particulate organic matter in Kiel Bight in relation to phytoplankton succession. Oceanol Acta 2:287-298

Souissi A, Souissi S, Yahia MND (2008) Temporal variability of abundance and reproductive traits of Centropages kroyeri (Calanoida; Copepoda) in Bizerte Channel (SW Mediterranean Sea, Tunisia). J Exp Mar Biol Ecol 355:125-136

Steidinger KA, Walker LM (1984) Marine plankton life cycle strategies. CRC Press, Boca Raton

Stottrup JG, Bell JG, Sargent JR (1999) The fate of lipids during development and cold-storage of eggs in the laboratory-reared calanoid copepod, Acartia tonsa Dana, and in response to different algal diets. Aquaculture 176:257-269

Tande K, Henderson RJ (1988) Lipid composition of copepodit stages and adult females of Calanus glacialis in Arctic waters of the Barents Sea. Polar Biol 8:333-339

Tang KW (2005) Copepods as microbial hotspots in the Ocean: effects of host feeding activities on attached bacteria. Aquat Microb Ecol 38:31-40

Tanskanen S (1994) Seasonal variability in the individual carbon content of the calanoid copepod Acartia bifilosa from the Northern Baltic Sea. Hydrobiologia 292(293):397-403
Thor P (2002) Elevated respiration rates of the neritic copepod Acartia tonsa during recovery from starvation. J Exp Mar Biol Ecol 327:1-11

Usov NV, Zubakha MA (2004) Temperature optimums of the White Sea zooplankton. Biol Morya (Mar Biol) 30:34-43

Vetrov AA (2008) Chlorophyll, primary production and organic carbon fluxes in the Kara Sea. Oceanology 48:33-42

Vieira L, Azeiteiro U, Re P, Pastorinho R, Marques JC, Morgado F (2003) Zooplankton distribution in a temperate estuary (Mondego estuary Southern arm: Western Portugal). Acta Oecol 24:S163S173

Viitasalo M, Koski M, Pellikka K, Johansson S (1995) Seasonal and long-term variations in the body size of planktonic copepods in the Nothern Baltic sea. Mar Biol 123:241-250

Wahlstroem E, Persson L, Diehl S, Bystroem P (2000) Size-dependent foraging efficiency, cannibalism and zooplankton community structure. Oecologia 123:138-148

Ward P, Shreeve R, Cripps GC (1996) Rhincalanus gigas and Calanus simillimus: lipid storage patterns of two species of copepods in the seasonaly ice-free zone of the Southern Ocean. J Plankton Res 18:1439-1454

Weisse T (1983) Feeding of calanoid copepods in relation to Phaeocystis pouchetii blooms off the German Wadden Sea area off Sylt. Mar Biol 74:87-94

Werner I, Auel H (2004) Environmental conditions and overwintering strategies of planktonic metazoans in and below coastal fast ice in the Gulf of Finland (Baltic Sea). Sarsia 89:296

Wu LS, Wang G-Zh, Jiang X-D, Li S-J (2007) Seasonal reproductive biology of Centropages tenuiremis (Copepoda) in Xiamen waters, China. J Plankton Res 29:437-446

Yoon WD, Shim MB, Choi JK (1998) Description of the development stages in Acartia bifilosa Giesbrecht (Copepoda: Calanoida). J Plankton Res 20:923-942 